\title{
Bioturbation in aquatic environments: linking past and present
}

\author{
Idea and coordination: Martin Solan, Liam G. Herringshaw
}

\section{CONTENTS}

Herringshaw LG, Solan M

Benthic bioturbation in the past, present and future

$201-205$

Teal LR, Bulling MT, Parker ER, Solan M

Global patterns of bioturbation intensity and

mixed depth of marine soft sediments

$207-218$

Maire O, Lecroart P, Meysman F, Rosenberg $R_{\text {, }}$

Duchêne JC, Grémare A

Quantification of sediment reworking rates in

bioturbation research: a review

$219-238$
Gingras MK, Dashtgard SE, MacEachern JA, Pemberton SG

Biology of shallow marine ichnology: a modern

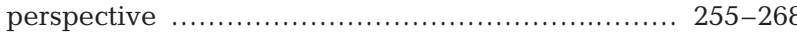

White DS, Miller MF

Benthic invertebrate activity in lakes: linking

present and historical bioturbation patterns

Herringshaw LG, Davies NS

Bioturbation levels during the end-Ordovician extinction event: a case study of shallow marine strata from the Welsh Basin $279-287$

Solan M, Batty P, Bulling MT, Godbold JA How biodiversity affects ecosystem processes: implications for ecological revolutions and benthic ecosystem function $289-301$

\section{Benthic bioturbation in the past, present and future}

\author{
Liam G. Herringshaw ${ }^{1, *}$, Martin Solan ${ }^{2}$ \\ ${ }^{1}$ Geology \& Petroleum Geology, School of Geosciences, Meston Building, University of Aberdeen, Aberdeen AB24 3 UE, UK \\ ${ }^{2}$ Oceanlab, University of Aberdeen, Main Street, Newburgh, Aberdeenshire AB41 6FL, UK
}

Understanding how ecosystems function at present is critical to any assessment of how they functioned in the past and of how they will function in the future. The geological record provides the dataset by which previous periods of environmental change can be examined and their consequences assessed. Ecological research, particularly predictive studies of ecosystem functioning, should therefore consider both modern and ancient case studies. Integrating research on bioturbation (the mixing of sediment by living organisms) with studies of trace fossils (ichnology) can provide a wealth of new information for aquatic biologists, ecologists, sedimentologists and palaeontologists. Bioturbation studies enable quantification of the behaviour of benthic organisms, their impact upon the environment, and their response to environmental change. In sedimentary rocks, ichnology may be the only means of assessing the organisms and ecosystems of the past. However, as noted by Meysman et al. (2006, p. 688), there is often 'a rather slow transfer of ideas' between workers in the 
two fields. Our aim in this Theme Section is to illustrate some of the many interesting topics in current bioturbation research for both modern and ancient eras, stimulate cross-disciplinary discussion, and highlight potentially fruitful areas of collaboration.

\section{Impacts of bioturbation on aquatic environments}

Bioturbation changes preserved in the rock record enable the recognition of 3 significant events in the evolution of aquatic ecosystems: the colonization of infaunal habitats in shallow marine settings, the colonization of the deep sea, and the colonization of freshwater environments. Infaunal activity was negligible in the Precambrian, but the Cambrian radiation of marine invertebrates led to a 'substrate revolution' (Bottjer et al. 2000). Through burrowing, feeding, ventilatory and locomotory behaviour, infauna altered biochemical and diagenetic reactions profoundly, and facilitated a radical redistribution of sediment particles and pore water across the sediment-water interface. Whilst the impact of bioturbation is species-specific and context dependent (e.g. Solan \& Kennedy 2002), it directly alters key ecosystem processes, including organic matter remineralisation and decomposition, nutrient cycling, pollutant release, sediment resuspension and microbial activity (see, inter alia, Rhoads 1974, Aller 1982, Krantzberg 1985). As bioturbating organisms evolved, a temporally and spatially dynamic mosaic of microenvironments was created, enabling the exploitation of new ecospace and the development of more complex and diverse benthic communities. Understanding and quantifying the mechanisms of bioturbation are therefore of primary importance for disentangling organism-sediment interactions as they relate to the provision and long-term sustainability of ecosystem function.

Restricted primarily to shallow marine environments during the Cambrian, complex, diverse bioturbation became prevalent in deep marine settings by the early Ordovician (Orr 2001). This offshore transition is attributed to an increasing competition for space and resources in shallow marine environments (Orr 2001) that led to the displacement of some groups of tracemakers (see also Crimes et al. 1992, Crimes 2001). Full details of the transition remain to be worked out, with deep marine strata of late Cambrian and early Ordovician age requiring further ichnological investigation, but the interpretation of its causes is generally accepted. The ecological and environmental effects of bioturbation in these deep marine environments have seen far less study, despite recognition that benthic biodiversity plays a key role in ecological and biogeochemical processes at a global scale (e.g. Danovaro et al. 2008).
The history of bioturbation in freshwater settings is less well understood than in marine environments, not least because trace fossils are comparatively uncommon in lacustrine and fluvial deposits (particularly the latter). The colonization of brackish water environments probably began in the Ediacaran (Buatois et al. 2005), but evidence of bioturbation in truly freshwater settings is lacking prior to the Cambro-Ordovician (see Buatois \& Mángano 2007). Furthermore, these Early Palaeozoic freshwater traces are epifaunal trackways from the margins of lakes (e.g. Johnson et al. 1994) and rivers (e.g. Wright et al. 1995). Traces recording the first freshwater infauna are much rarer, and their age less well constrained. The ichnotaxa described from fluvial channels and inter-dune ponds in the Tumblagooda Sandstone of Australia are probably late Silurian in age (Trewin \& McNamara 1995), but palaeomagnetic data has been used to suggest that the sediments were deposited in the Ordovician (Schmidt \& Hamilton 1990). Whichever age is correct, these domichnia (dwelling burrows) are the oldest freshwater examples known, but resolution of the geochronology is critical to establishing when such substrates were first colonized by infaunal organisms. The early evolution of terrestrial ecosystems is incompletely understood, and future ichnological studies have the potential to provide many new insights.

\section{Effects of environmental change on bioturbation}

The effects of biodiversity loss on bioturbation are beginning to be recognised (Solan et al. 2008, this Theme Section), but little is known about how bioturbation processes are affected by progressive species loss under realistic extinction scenarios (Solan et al. 2004). Five major extinctions are recognized in the Phanerozoic: the late Ordovician, late Devonian, endPermian, late Triassic, and end-Cretaceous events. The nature of these events was determined primarily using body fossils, and only recently have researchers begun examining the intervals for ichnological changes. Parameters such as burrow size and bioturbation depth can be used as proxies for ecological stress; Twitchett $\&$ Barras (2004) highlighted the value of such measurements in determining the ecological aftermath of extinction events. In stratigraphic successions of sufficiently high resolution, the same approach could be applied to the onset and duration of extinctions. There is a noticeable paucity of work on the late Ordovician and late Devonian events; most research so far has focused on the end-Permian and end-Cretaceous extinctions. Herringshaw \& Davies (2008, this Theme Section) have studied ichnological changes in the late Ordovician of the Welsh Basin, but more work needs to 
be conducted over a much broader geographical area, and for all extinction intervals. In terms of predicting future change, research into extinctions driven by intrinsic mechanisms such as eustatic sea level change (rather than extrinsic events such as meteorite impacts) could be especially informative.

Anthropogenic stresses, including overfishing, habitat destruction and pollution are amongst the most immediate threats to the persistence of sedimentdwelling invertebrates in present day coastal and deep-sea benthic habitats. However, knowledge of the effects of species loss on human welfare is limited by a lack of fine-scale data for these systems. Few biodiversity-ecosystem function protocols actually include the environmental context surrounding an extinction event, or the specific cause of extinction. Instead, investigators opt for a design that assumes random biodiversity loss as a consequence of an unspecified forcing, despite the wealth of information accessible from the palaeoecological community. Recent work indicates that the effect of extinction on ecosystem processes depends on the type of extinction driver (Solan et al. 2004) and whether or not species have identical extinction risks (Gross \& Cardinale 2005). Thus, a disconnection exists between the representation of biodiversity loss scenarios in experimental systems and the context in which biodiversity-ecosystem process relations are moderated in the real world and under stress. A better understanding of these links is critical for underpinning marine conservation initiatives and policy decisions regarding the sustainability of natural marine resources in the face of the major challenges posed by global environmental change.

\section{Bioturbation and behaviour}

One of the intractable problems facing ichnologists is assigning trace fossils to the organisms that produced them. Studies of analogous structures produced by extant taxa, however, are useful for establishing a plausible list of candidates, and the likely behaviour of the tracemaker. Gingras et al. (2008, this Theme Section) have examined traces produced by shallow marine organisms, enabling their comparison with trace fossils from similar environments. Their results show that we can be fairly confident about the origin of some trace fossils, but also that similar structures can be produced by different taxa behaving in very different ways. Traces morphologically equivalent to the ichnogenus Gyrolithes, for example, are produced by worms anchoring themselves to the seabed, and by ramp-building shrimps (Gingras et al. 2008). This highlights the risk of interpreting trace fossils definitively, but further studies of this kind can provide greater clarity.
For ecologists and ichnologists interested in lacustrine bioturbation, the problems are arguably greater. Compared with marine environments, modern lakes are inhabited by significantly fewer burrowing organisms. Lakes are also subject to major seasonal and regional variations, and lacustrine facies are scarce in the rock record. White \& Miller $(2008$, this Theme Section) note that bioturbation in lakes has seen little research, and studies comparing modern traces with the ichnological record are especially scarce. There are also terminological issues: the intrinsic variability of lakes makes the broadly constant terms of marine ecology and geology difficult to apply, and many limnological (and some oceanographic) terms are defined biologically, such as the littoral zone. In marine environments, this is described commonly as the part of the shoreline that is exposed at low tide and submerged at high tide, though it is also defined using the distribution of key plant and animal taxa (see e.g. Lewis 1961). In lakes, however, it is defined as the zone to which light penetrates sufficiently for macrophytes to photosynthesize, typically measured as $1 \%$ of the surface light intensity (see e.g. Loeb et al. 1983). This definition cannot be applied satisfactorily to lacustrine strata, as light penetration levels are almost impossible to determine in the rock record, whilst macrophytes are rarely fossilized in situ. Instead, the grain size and sedimentary structures are used to assess the energy regime under which sediments were deposited, with coarser material indicating a more proximal setting. Resolving this dichotomy is difficult, but comparisons of trace fossils with bioturbation in modern lakes may enable identification of assemblages diagnostic of particular lake zones. Work of this nature has begun, but only 2 trace fossil assemblages (ichnofacies) have been recognized thus far, both of which can occur in a variety of freshwater sub-environments (see Buatois \& Mángano 2007).

\section{Bioturbation depth over time and space}

The mean global depth of marine bioturbation was calculated by Boudreau (1994) to be $98 \pm 45 \mathrm{~mm}$ (mean $\pm \mathrm{SD}$ ), a value revised only very slightly (to $97 \mathrm{~mm}$ ) by later modelling (Boudreau 1998). New work by Teal et al. (2008, this Theme Section) produces a value of $57.5 \pm 56.7 \mathrm{~mm}$, but illustrates how variable the available data are, regionally and bathymetrically, observing that 'we have reasonable estimates of bioturbation for only a limited set of conditions and regions of the world' (Teal et al. 2008, p. 207). This probably applies to ichnology also, with European and North American trace fossils having been studied for far longer than those of Asia, Africa and South America. 
The importance of time scales should also be emphasized. Measurements of bioturbation are tracerdependent, so different tracer longevities will give different results, particularly if areas are subject to bioturbation 'events' separated by many years. Maire et al. (2008, this Theme Section) review the different methods currently available to assess sediment reworking by benthic infauna using living organisms, and Meysman et al. (2008, this Theme Section) provide guidance on which method is most appropriate for short-term bioturbation studies. In such experiments, the integration of bioturbation events over time may influence the interpretation of natural mixing processes at short time scales, a problem that is also highly relevant to the extended time-series data on bioturbation in the rock record. Ichnofabrics preserved in sedimentary rocks, for example, are often a time-averaged record of the activity of more than one community (Ekdale et al. 1984, Pickerill 1992, McIlroy 2004), but it is possible to identify ichnofabrics formed by a single community or succession of closely similar communities (Ekdale et al. 1984, McIlroy 2004). With a suitable quantity of data, variations in mean mixed depth over geological timescales would therefore be a potential avenue of exploration. For the prediction of ecosystem responses to biodiversity loss at the present day, variations in bioturbation depth during previous extinction events could also be utilized. Boudreau (1994, 1998) argued that the mean mixed depth in modern oceans is effectively independent of variations in water depth and sedimentation rate (but see Middelburg et al. 1997). This was probably not the case in the early Palaeozoic, as deep marine environments in the Cambrian had lower ichnological diversity and more limited colonization than post-Cambrian equivalents (Orr 2001), but its applicability to later Palaeozoic, Mesozoic and Cenozoic strata has yet to be investigated.

\section{LITERATURE CITED}

Aller RC (1982) The effects of macrobenthos on chemical properties of marine sediment and overlying water. In: McCall PL, Tevesz MJS (eds) Animal-sediment relations: the biogenic alteration of sediments. Top Geobiol 2: 53-102

Bottjer DJ, Hagadorn JW, Dornbos SQ (2000) The Cambrian substrate revolution. Geol Soc Am Today 10:1-7

Boudreau BP (1994) Is burial velocity a master parameter for bioturbation? Geochim Cosmochim Acta 58: 1243-1249

Boudreau BP (1998) Mean mixed depth of sediments: the wherefore and the why. Limnol Oceanogr 43:524-526

Buatois LA, Mángano MG (2007) Invertebrate ichnology of continental freshwater environments. In: Miller W (ed) Trace fossils: concepts, problems, prospects. Elsevier, Amsterdam, p 285-323

Buatois LA, Gingras MK, MacEachern J, Mángano MG and others (2005) Colonization of brackish-water systems through time: evidence from the trace-fossil record. Palaios 20:321-347

Crimes TP (2001) Evolution of the deep-water benthic community. In: Zhuravlev AY, Riding R (eds) The ecology of the Cambrian radiation. Columbia University Press, New York, p 275-297

Crimes TP, Garcia Hidalgo JF, Poire DG (1992) Trace fossils from the Arenig flysch sediments of Eire and their bearing on the early colonisation of the deep seas. Ichnos 2:61-77

Danovaro R, Gambi C, Dell'Anno A, Corinaldes C and others (2008) Exponential decline of deep sea ecosystem functioning linked to benthic biodiversity loss. Curr Biol 18: $1-8$

Ekdale AA, Bromley RG, Pemberton SG (1984) Ichnology: trace fossils in sedimentology and stratigraphy. SEPM Short Course 15, Society of Economic Palaeontologists and Mineralogists, Tulsa, OK

Gingras MK, Dashtgard SE, MacEachern JA, Pemberton SG (2008) Biology of shallow marine ichnology: a modern perspective. Aquat Biol 2:255-268

Gross K, Cardinale BJ (2005) The functional consequences of random vs. ordered species extinctions. Ecol Lett 8: $409-418$

Herringshaw LG, Davies NS (2008) Bioturbation levels during the end-Ordovician extinction event: a case study of shallow marine strata from the Welsh Basin. Aquat Biol $2: 279-287$

Johnson EW, Briggs DEG, Suthren RJ, Wright JL, Tunnicliff SP (1994) Non-marine arthropod traces from the subaerial Ordovician Borrowdale Volcanic Group, English Lake District. Geol Mag 131:395-406

Krantzberg G (1985) The influence of bioturbation on physical, chemical, and biological parameters in aquatic environments: a review. Environ Pollut Ser A Ecol Biol 39: 99-102

- Lewis JR (1961) The littoral zone on rocky shores: A biological or physical entity? Oikos 12:280-301

Loeb SL, Reuter JE, Goldman CR (1983) Littoral zone production of oligotrophic lakes: the contributions of phytoplankton and periphyton. In: Wetzel RG (ed) Periphyton of freshwater ecosystems. Dr. W. Junk Publishers, Den Haag, p 161-167

Maire O, Lecroart P, Meysman F, Rosenberg R, Duchêne JC, Grémare A (2008) Quantification of sediment reworking rates in bioturbation research: a review. Aquat Biol 2: 219-238

McIlroy D (2004) Some ichnological concepts, methodologies, applications and frontiers. In: Mcllroy D (ed) The application of ichnology to palaeoenvironmental and stratigraphic analysis. Spec Pub 228, Geol Soc London Publishing House, Bath, p 3-27

> Meysman FJR, Middelburg JJ, Heip CHR (2006) Bioturbation: a fresh look at Darwin's last idea. Trends Ecol Evol 21: 688-695

Meysman FJR, Malyuga VS, Boudreau BP, Middelburg JJ (2008) Quantifying particle dispersal in aquatic sediments at short time scales: model selection. Aquat Biol 2:239-254

Middelburg JJ, Soetaert K, Herman PKJ (1997) Empirical relationships for use in global diagenetic models. DeepSea Res I 44:327-344

$>$ Orr PJ (2001) Colonization of the deep-marine environment during the early Phanerozoic. Geol J 36:265-278

Pickerill RK (1992) Carboniferous nonmarine invertebrate ichnocoenoses from southern New Brunswick, eastern Canada. Ichnos 2:21-35

Rhoads DC (1974) Organism-sediment relations on the muddy sea floor. Oceanogr Mar Biol Annu Rev 12:263-300 
Schmidt PW, Hamilton PJ (1990) Palaeomagnetism and the age of the Tumblagooda Sandstone, Western Australia. Aust J Earth Sci 37:381-385

Solan M, Kennedy R (2002) Observation and quantification of in situ animal-sediment relations using time-lapse sediment profile imagery (t-SPI). Mar Ecol Prog Ser 228: 179-191

Solan M, Cardinale BJ, Downing AL, Engelhardt KAM, Ruesink JL, Srivastava DS (2004) Extinction and ecosystem function in the marine benthos. Science 306: $1177-1180$

Solan M, Batty P, Bulling MT, Godbold JA (2008) How biodiversity affects ecosystem processes: implications for ecological revolutions and benthic ecosystem function. Aquat Biol 2:289-301

Teal LR, Bulling MT, Parker ER, Solan M (2008) Global patterns of bioturbation intensity and the mixed depth of marine soft sediments. Aquat Biol 2:207-218

Trewin NH, McNamara KJ (1995) Arthropods invade the land: trace fossils and palaeoenvironments of the Tumblagooda Sandstone (?late Silurian) of Kalbarri, Western Australia. Trans R Soc Edinb 85:177-210

Twitchett RJ, Barras CG (2004) In: McIlroy D (ed) The application of ichnology to palaeoenvironmental and stratigraphic analysis. Spec Pub 228, Geol Soc London Publishing House, Bath, p 397-418

White DS, Miller MF (2008) Benthic invertebrate activity in lakes: linking present and historical bioturbation patterns. Aquat Biol 2:269-277

Wright JL, Quinn L, Briggs DEG, Williams SH (1995) A subaerial arthropod trackway from the upper Silurian Clam Bank Formation of Newfoundland. Can J Earth Sci 32:304-313 